\title{
LETTERS
}

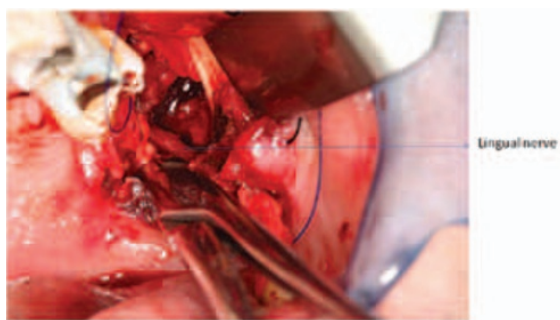

Fig. 1 The needle was found positioned medial to the lingual nerve

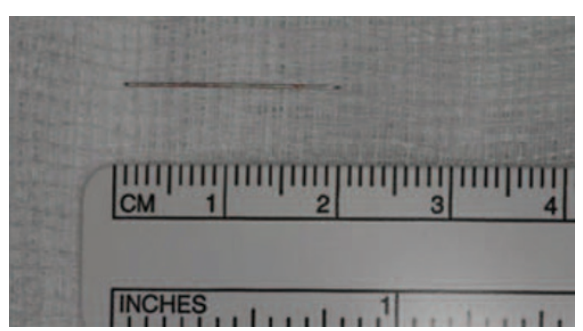

Fig. 2 The $20 \mathrm{~mm}$ retrieved needle

migration into vital structures and also to minimise long term morbidity for the patient. Complications include trismus, pain, infection, and damage to the inferior alveolar and lingual nerves. ${ }^{1}$

To prevent needle breakage practitioners should use 27-gauge $35 \mathrm{~mm}$ needles for IAN block, avoid inserting to full length or burying the needle in the tissues, ensure patient cooperation thus avoiding sudden movements, and avoid bending needles or changing direction while still located deep in the tissues or exerting lateral pressure on withdrawal. ${ }^{3}$

A. Bawor-Omatseye, A. Majumdar By email

1. Ethunandan $M$, Tran A L , Bowden J, Seal M T Brennan P A. Needle breakage following inferior alveolar nerve block: implications and management. Br Dent J 2007; 202: 395-397.

2. Thompson M, Wright S, Cheng L H, Starr D. Locating broken dental needles. Int J Oral Maxillofac Surg 2003; 32: 642-644.

3. Augello M, von Jackowski J, Gratz K W, Jacobsen $C$. Needle breakage during local anaesthesia in the oral cavity - a retrospective study of the last 50 years with guidelines for treatment and prevention. Clin Oral Investig 2011; 15: 3-8.

DOI: 10.1038/sj.bdj.2013.795

\section{TONGUE CANCER SUBGROUP}

Sir, we are writing to share our concerns about the delayed diagnosis of oral cancer among non-smoking women in Jordan which we think may have wider implications.

Over the last year, we have seen four female patients with tongue cancer (Fig. 1). They were aged over 40 except one who was 38 years old. None of them had the classical risk factors for oral cancer; they were non-smokers and non-alcohol drinkers. They were seen by a substantial number of physicians and dentists mainly for the same complaint of a non-healing ulcer on the right aspect of the tongue posteriorly. No-one suspected that this was oral cancer because the patients were female and non-smokers. In each case biopsy was delayed and eventually diagnosis was reached at a late stage when the cancer became advanced, worsening the prognosis.

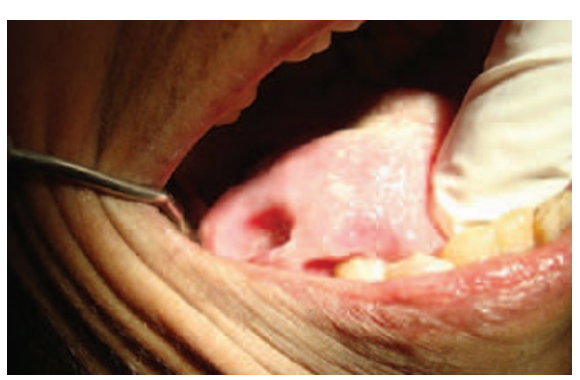

Fig. 1 A 70-year-old female had been complaining of a sore tongue for eight months. No treatment was provided by her physician apart from mouthwash and antibiotics. Later on, her tongue became immobile, numb and she suffered difficulty with speech and swallowing

A recent Australian study pointed to a growing subgroup of oral cancer patients who are non-smokers and non-drinkers. According to Koo et al., ${ }^{1}$ this group of patients has a significantly worse disease-specific mortality, and they explain this by the presence of certain aetiological and genetic differences in tumours between this and the smoker group, resulting in either more locally aggressive disease or an increased likelihood of nodal and distant spread. Environmental exposure to secondhand smoke could be a major confounding factor. Kansy et al. ${ }^{2}$ suggest that high-risk HPV infection is a predominant factor in the development of oral squamous cell carcinoma (OSCC) in patients who do not smoke or drink. On the other hand, Koo et al. ${ }^{1}$ suggest that HPV may confer a worse prognosis in tumours of the tongue, and as tobacco use decreases, they predict that the proportion of this group among OSCC patients will increase.

Dentists and physicians alike should be aware that female non-smokers can get oral cancer, and that of those diagnosed, the prognosis can be poor. Diagnosis should be established as early as possible by not neglecting any persistent lesion, particularly if it is an ulcer affecting the tongue. Patients would probably go to their physicians or dentists for reassurance regarding such lesions. Appropriate procedures like early referral and histopathological examination could save a patient's life or at least improve treatment outcomes and quality of life.

N. Dar-Odeh, O. Abu-Hammad, Amman

1. Koo K, Barrowman R, McCullough M, Iseli T, Wiesenfeld D. Non-smoking non-drinking elderly females: a clinically distinct subgroup of oral squamous cell carcinoma patients. Int J Oral Maxillofac Surg 2013; 42: 929-933.

2. Kansy K, Thiele O, Freier K. The role of human papillomavirus in oral squamous cell carcinoma: myth and reality. Oral Maxillofac Surg 2012; DOI: 10.1007/s10006-012-0383-0.

DOI: 10.1038/sj.bdj.2013.796

\section{DIFFERENT PERSPECTIVES}

Sir, in response to Mr Roy Abrahams (BDJ 2013; 215: 4), it is interesting how easy it is for people to remember events from different perspectives. David DiBiase did indeed agree with me to undertake a pilot project comparing the correction of ten millimetre overjets (OJ) by straight wire or orthotropics. It was a shame that he never released the facial images of the end results which was the intended purpose of the study, and also that he did not agree to progress to the main study, despite a highly significant $25^{\circ}$ difference in growth direction. Prospective orthodontic comparisons are rare enough and this unfortunately gave the impression of exclusion.

Personally I do not remember any other offers of research and there has certainly never been an independent assessment of orthotropics. However, it is never too late, and considering that Roy is correcting $12 \mathrm{~mm}$ 0Js as bread and butter may I again offer to cooperate with him in a comparative orthodontic and orthotropic research project of ten millimetre overjets as it really matters to know the truth?

J. Mew

The London School of Facial Orthotropics DOI: 10.1038/sj.bdj.2013.797

\section{DIODONTIC IMPLANT}

Sir, a male 41-year-old army officer presented for a periodic dental inspection. On examination a metal ceramic crown was noted on the upper right central 
incisor and review of his radiographic records showed a long diodontic implant (material unknown) in place, retaining the crown, and extending almost to the base of the nasal cavity. Surprising is the appearance on the radiograph (Fig. 1), showing extensive root fracturing in the mid and coronal portions. Despite this, there is no evidence of bone loss, resorption or ankylosis radiographically. The tooth presents no associated soft tissue abnormality, mobility or periodontal pocketing clinically.

As to the history of this tooth, the patient reported having clashed heads during a rugby match aged nine, and this tooth being subluxed well into the palate, with the crown sheared off 'almost to gum level'. The first attendant dentist reduced the luxation on the day, and used the recovered natural coronal portion as a temporary restoration. The patient's own dentist placed the implant a week later, again using the natural tooth as a temporary restoration. The existing crown was placed ten years ago once the natural tooth had become discoloured.

The patient's main recollection of the event was that his mother dropped him at the surgery and went shopping for the hour required to complete the procedure.

The endodontic-endosseous (EE, diodontic, or trans-radicular) implant has been in reported use as far back as Pharaonic times. Modern history shows this modality gaining popularity in the 1960s, particularly in the USA.

For reasons including poor case selection, improper use of materials and poor bone bed preparation for the implant,

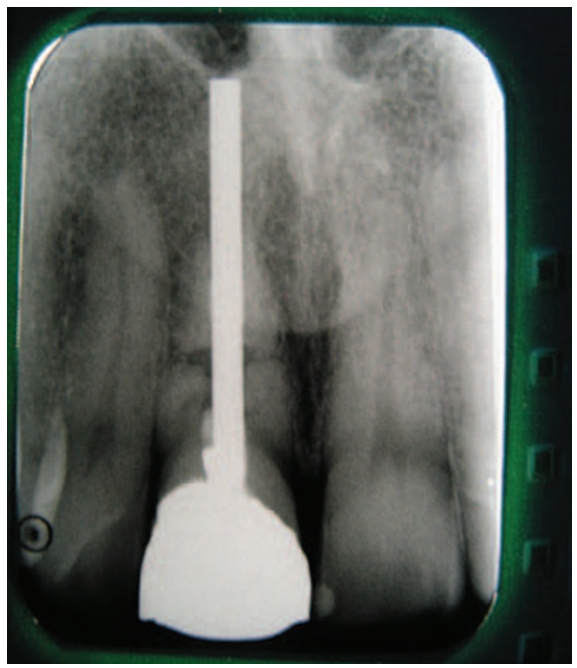

Fig. 1 Long diodontic implant as well as post operative infection, this treatment modality suffered high failure rates. Common materials used for the implant post were steel, cobalt chrome, vitallium alloy, titanium, as well as hydroxyapatite-surfaced metals. ${ }^{2}$.

The procedure fell into disuse, largely due to the predictability of osseo-integrated endosseous implants, in the West at least. Although the conventionally published literature (mostly case reports and commentaries) peters out for EE implants during the early 1990 s $^{3}$ it seems from wider online searches that this is still very much in use in developing parts of the world including Egypt!

\section{W. Slim, Royal Army Dental Corps, Bielefeld}

1. Weine F S, Frank A L. Survival of the endodontic endosseous implant. J Endod 1993; 19: 524-528.

2. Larsen R M, Patten J R, Wayman B E. Endodontic endosseous implants: case reports and update of material. J Endod 1989; 15: 496-500.

3. Ingles Endodontics \#6. Berkshire, UK: McGraw Hill Education, 2008.

DOI: 10.1038/sj.bdj.2013.798

\section{DEATH OF A PASTRY CHEF}

Sir, the recent forensic anthropological examination of the skull of MarieAntoine Carême (1784-1833) brought to light a clear cause of death directly related to poor dental status.

Carême, a nineteenth century French pâtissier, is considered the first internationally renowned celebrity chef, and the creator of the standard chef's hat, the toque. ${ }^{1}$ He served as a chef de cuisine to Talleyrand, Napoléon, Tsar Alexander I and banker James Mayer Rothschild. He published several books on cookery, above all the encyclopaedic Art of French cookery, translated in London in 1836. ${ }^{2}$ He died in Paris at the age of 48. The cause of death was considered to be chronic carbon monoxide intoxication and/or anthracosis (due to too many years inhaling the toxic fumes of the charcoal on which he cooked). ${ }^{1}$

Carême's skull is preserved in the National Museum of Natural History (Paris, France), as a part of the phrenological collection of Dumoutier (MNHNHA-29888). ${ }^{3}$ Its state of preservation is perfect (Fig. 1). The rest of the body (including the mandible) has been buried and remain, to date, non-observable.

The external examination of the maxillary shows the persistence of only one

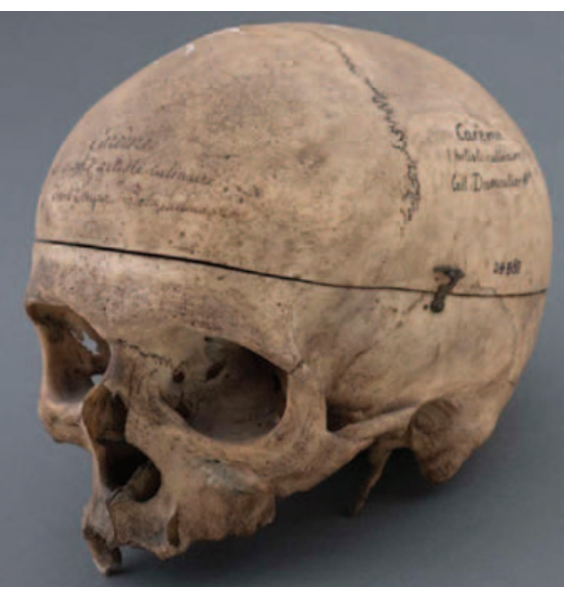

Fig. 1 Carême's skull (picture by MNHN, anthropological collections)

tooth (14), and an extensive ante-mortem and post-mortem tooth loss (respectively: 11, 12, 13, 15, 16 ,17, 18, 21, 22, 23, 24, 25, 26, 27). $5 \mathrm{~mm}$ - and $8 \mathrm{~mm}$-length abscesses existed directly related to teeth 16 and 27, this last communicating with the maxillary sinus through a bone opening of $3 \mathrm{~mm}$. Only a fragment of the 16 was still present at the time of death, inserted in the maxillary bone, maybe as a result of an incomplete tooth extraction during dental surgery.

This poor dental status is directly related to the occupational activities of Carême, ie the professional confection of pastries. Previous studies have shown the implication of personal and professional factors in the development of sugar caries, such as manipulation of sugars, frequent tasting of sweet dishes, sieving of icing sugar, etc. ${ }^{4-7}$ Local infectious complications (maxillary sinusitis) may have played a direct role in the cause of death of the first celebrity chef.

\section{Philippe, Paris}

1. Kelly I. Cooking for the kings: the life of Antoine Carême, the first celebrity chef. London: Walker \&t Co, 2004.

2 Rambourg P. Histoire de la cuisine et de la gastronomie françaises. Paris: Perrin, 2010.

3. Livianos-Aldana L, Rojo-Moreno L, Sierra-Sanmiguel P. F. J. Gall and the phrenological movement. Am J Psychiatry 2007; 164: 414

4. Frazao P. Epidemiology of dental caries: when structure and context matter. Braz Oral Res 2012; 26 Suppl 1: 108-114.

5. Johansson I, Holgerson P L, Kressin N R, Nunn M E, Tanner A C. Snacking habits and caries in young children. Caries Res 2010; 44: 421-430.

6. Mäkinen K K. Sugar alcohols, caries incidence, and remineralization of caries lesions: a literature review. Int J Dent 2010; 2010: 981072.

7. Toro E, Nascimento M M, Suarez-Perez E, Burne R A, Elias-Boneta A, Morou-Bermudez E. The effect of sucrose on plaque and saliva urease levels in vivo. Arch Oral Biol 2010; 55: 249-254.

DOI: 10.1038/sj.bdj.2013.799 